\title{
Exogenous short-term silicon application regulates macro-nutrients, endogenous phytohormones, and protein expression in Oryza sativa $\mathrm{L}$.
}

Soo-Won Jang ${ }^{1+}$, Yoonha Kim ${ }^{2 \dagger}$, Abdul Latif Khan ${ }^{3}$, Chae-In Na ${ }^{4}$ and In-Jung Lee $2,5^{*}$

\begin{abstract}
Background: Silicon (Si) has been known to regulate plant growth; however, the underlying mechanisms of shortterm exogenous Si application on the regulation of calcium (Ca) and nitrogen (N), endogenous phytohormones, and expression of essential proteins have been little understood.

Results: Exogenous Si application significantly increased Si content as compared to the control. Among Si treatments, $1.0 \mathrm{mM}$ Si application showed increased phosphorus content as compared to other Si treatments $(0.5$, 2.0, and $4.0 \mathrm{mM}$ ). However, Ca accumulation was significantly reduced (1.8- to 2.0-fold) at the third-leaf stage in the control, whereas all Si treatments exhibited a dose-dependent increase in $\mathrm{Ca}$ as determined by radioisotope ${ }^{45} \mathrm{Ca}$ analysis. Similarly, the radioisotope ${ }^{15} \mathrm{~N}$ for nitrogen localization and uptake showed a varying but reduced response (ranging from 1.03-10.8\%) to different Si concentrations as compared to ${ }^{15} \mathrm{~N}$ application alone. Physiologically active endogenous gibberellin $\left(\mathrm{GA}_{1}\right)$ was also significantly higher with exogenous $\mathrm{Si}(1.0 \mathrm{mM})$ as compared to $\mathrm{GA}_{20}$ and the control plants. A similar response was noted for endogenous jasmonic and salicylic acid synthesis in rice plants with Si application. Proteomic analysis revealed the activation of several essential proteins, such as Fe-S precursor protein, putative thioredoxin, Ser/Thr phosphatase, glucose-6-phosphate isomerase (G6P), and importin alpha-1b (Imp3), with Si application. Among the most-expressed proteins, confirmatory gene expression analysis for G6P and Imp3 showed a similar response to those of the Si treatments.
\end{abstract}

Conclusions: In conclusion, the current results suggest that short-term exogenous Si can significantly regulate rice plant physiology by influencing $\mathrm{Ca}$, $\mathrm{N}$, endogenous phytohormones, and proteins, and that $1.0 \mathrm{mM}$ Si application is more beneficial to plants than higher concentrations.

Keywords: Silicon application, Gibberellins, Jasmonic acid, Glucose-6-phosphate isomerase, Importin alpha 1b, Protein expression, Radioisotope ${ }^{45} \mathrm{Ca}$

\section{Background}

During the past several decades, scientists have focused on the role of silicon $(\mathrm{Si})$ in various crops, such as barley $[1,2]$, cucumber [3], maize [1], rice [4-7], soybean [8], and tomato [9]. Si is the second most abundant element in soil, following oxygen [10], and is found as silica $\left(\mathrm{SiO}_{2}\right)$, silicic acid

\footnotetext{
* Correspondence: ijlee@knu.ac.kr

${ }^{\dagger}$ Equal contributors

2Division of Plant Biosciences, Kyungpook National University, Daegu 41566, South Korea

${ }^{5}$ Crop Physiology Laboratory, Division of Plant Biosciences, Kyungpook

National University, Daegu 41566, South Korea

Full list of author information is available at the end of the article
}

$\left(\mathrm{H}_{4} \mathrm{SiO}_{4}\right)$, and silicate $\left(\mathrm{xM}_{2}^{1} \mathrm{OySiO}{ }_{2}\right)$ because of its strong affinity for other ions [11]. Higher plants usually take up aqueous silicic acid from the rhizosphere through their roots [12]. In rice plants, Ma et al. [7] reported that two specific genes (OsLsi1 and OsLsi2) were involved in Si transfer between the rhizosphere and xylem. Si enters the shoot part with the help of OsLsi6, transporting Si into the xylem parenchyma region and then into the silicified cells of leaf blades [13]. During transport of $\mathrm{Si}$, transport-related genes are activated and calcium (in $\mathrm{Ca}^{2+}$ form) is actively taken up through the solute gradient in either an apoplastic or a 
symplastic manner $[14,15]$. In most cases, both $\mathrm{Si}$ and $\mathrm{Ca}$ are transported via the Casparian strip [15]. Cytosolic $\mathrm{Ca}^{2+}$ contributes to various physiological responses, such as opening stomatal guard cells, phototropism, and responses to gravity [16]. In addition, nitrogen $(\mathrm{N})$ uptake, transportation, and distribution influence plant cell physiology and growth $[17,18]$. Some recent studies have demonstrated ameliorative actions of $\mathrm{N}$ and $\mathrm{Si}$ [19-21]. The endogenous and exogenous $\mathrm{Si}$ and $\mathrm{Ca}^{2+}$ oscillation perturbs plant growth dynamics and responses to stress conditions [22].

In plants, $\mathrm{Si}$ absorbed from the soil creates silica cells or silica bodies and has been shown to confer tolerance to various biotic and abiotic stresses [13]. In addition to the role of $\mathrm{Si}$ in enhancing resistance to environmental stress, it can induce various physiological responses, such as regulation of antioxidant activity, modulation of endogenous hormones, alteration of mineral uptake, and promotion of adventitious shoot regeneration [11, 23-25]. Particularly under field conditions, Si application to rice not only induces an increase in plant height and culm length by upregulation of bioactive gibberellin (GA), but also reinforces cell walls. Subsequently, rice plants have greater photosynthetic efficiency and these physiological responses directly affect yield components [10, 23, 26-28].

The role of $\mathrm{Si}$ in higher plants has been well-described in various studies $[4-7,10,29]$. In particular, research related to Si-mediated abiotic and biotic stress amelioration is substantial [10]. For example, cadmium uptake was significantly reduced in Si-treated rice plants because of the regulation of P1-type ATPase [4]. Si application to wheat seedlings also resulted in UV stress mitigation through regulation of antioxidant activities such as ascorbate peroxidase (APX), catalase (CAT), and superoxide dismutase (SOD) [30]. In addition to its effects related to abiotic stress, $\mathrm{Si}$ can induce resistance against powdery mildew diseases in cucumber, barley, and strawberries, as well as suppress the spread of rice blast disease [31]. Previous studies have shown that $\mathrm{Si}$ can mitigate diverse abiotic and biotic stress; however, the underlying influences and changes in mineral uptake, especially $\mathrm{Ca}$ and $\mathrm{N}$ localization and uptake, have been little understood. Additionally, the effects of short-term application of different $\mathrm{Si}$ concentrations on the expression of specific proteins and genes are poorly described. The aim of this study was to elucidate the effects of short-term exogenous $\mathrm{Si}$ application on the uptake of $\mathrm{Ca}$ and $\mathrm{N}$ as well as on the regulation of endogenous phytohormones (gibberellins [GA], jasmonic acid [JA], and salicylic acid [SA]) and related protein expression in rice plants.

\section{Methods}

Plant materials and growth conditions

Oryza sativa L. 'Dongjin' seeds were procured from the National Institute of Crop Science, Rural Development
Administration, The Republic of Korea, to perform Sirelated experiments. The seeds were sterilized with $5 \%$ sodium hypochlorite for $10 \mathrm{~min}$ and thoroughly washed with autoclaved double-distilled water (DDW). After 3 days of soaking in DDW, germinated rice seedlings were transplanted into thoroughly autoclaved sand medium and placed into a growth chamber (KGC-175 VH, Koencon, South Korea) for 2 weeks to obtain uniform seedling growth. During the experiment, growth chamber conditions were adjusted to 12-h light (08:0020:00 h, $30{ }^{\circ} \mathrm{C}$, relative humidity $70 \%$ ) and 12 -h dark (20:00-08:00 h, $25{ }^{\circ} \mathrm{C}$, relative humidity $70 \%$ ). Yoshida solution was used as the nutrient source [32]. The solution $\mathrm{pH}$ was maintained daily at $5.0-5.3$ by adding $\mathrm{HCl}$ to the medium to reduce the polymerization of silicates [5]. After 2 weeks, fully grown rice plants were transplanted to pots $(25 \mathrm{~cm} \times 20 \mathrm{~cm} \times 20 \mathrm{~cm})$ and supplied with DDW for 3 days to remove nutrients and sand medium. The rice plants were then used as experimental material.

\section{Silicon application to rice plants}

The rice plants were treated with four different concentration of $\mathrm{Si}\left(\mathrm{Na}_{2} \mathrm{SiO}_{3} .9 \mathrm{H}_{2} \mathrm{O} ; 0.5 \mathrm{mM}, 1.0 \mathrm{mM}, 2.0 \mathrm{mM}\right.$, and $4.0 \mathrm{mM}$ ) in $4 \mathrm{~L}$ DDW for $24 \mathrm{~h}$ in the growth chamber as described earlier. The rice plant samples were harvested at three time periods: $6 \mathrm{~h}, 12 \mathrm{~h}$, and $24 \mathrm{~h}$ following $\mathrm{Si}$ application. Each treatment had three replications and each replicate comprised 24 plants. All the samples were harvested in liquid nitrogen to perform phytohormonal, proteomics, and biochemical analysis. Each analysis was replicated three times.

\section{Determination of mineral content after Si application}

The rice plants $(1.0 \mathrm{~g})$ were soaked in $0.5 \mathrm{M} \mathrm{HCl}$ for $20 \mathrm{~s}$, rinsed with DDW, and dried for $72 \mathrm{~h}$ in an oven at $70{ }^{\circ} \mathrm{C}$. Samples were weighed, ground to fine powder, and digested in $5 \mathrm{~mL}$ of a tertiary mixture of $\mathrm{HNO}_{3}: \mathrm{H}_{2-}$ $\mathrm{SO}_{4}: \mathrm{HClO}_{4}(10: 1: 4, v / v)$. The $\mathrm{Si}$ content was determined by inductively coupled plasma mass spectrometry (Optima 7900DV, Perkin-Elmer, Waltham, MA, USA) as shown by [5]. The experiment was repeated three times.

\section{Determination of endogenous phytohormones}

The levels of GA and JA from whole shoot samples were determined. For GA analysis, we used $0.5 \mathrm{~g}$ freeze-dried plant samples. The extraction and quantification of $\mathrm{GA}_{20}$ and $\mathrm{GA}_{1}$ were conducted using an established protocol [33]. Deuterated $\mathrm{GA}_{20}\left({ }^{2} \mathrm{H}_{2} \mathrm{GA}_{20}\right)$ and $\mathrm{GA}_{1}$ $\left({ }^{2} \mathrm{H}_{2} \mathrm{GA}_{1}\right)$ were used as internal standards, and as such, $20 \mathrm{ng}$ of each standard was added during the extraction process. A $0.5 \mathrm{~g}$ of plant sample was extracted with $80 \%$ and $100 \%$ methanol $(\mathrm{MeOH})$. This solution was refrigerated for $1 \mathrm{~h}$ at $-70{ }^{\circ} \mathrm{C}$ and then filtered by a GF/A filter 
to remove chlorophyll. The extracted sample was passed through a 5 g C18 column (90-130 $\mu \mathrm{m}$; Alltech, Deerfield, IL, USA) and dried on $1 \mathrm{~g}$ Celite. The dried Celite was loaded into $5 \mathrm{~g}$ of silicon dioxide $\left(\mathrm{SiO}_{2}\right)$. Additionally, the extracted sample was mixed with polyvinylpolypyrrolidone (PVPP, Sigma Aldrich, USA) for $1 \mathrm{~h}$ and then the mixture was filtered. The extracted sample was partitioned three times with equal volumes of EtOAc. The EtOAc fraction was dried in a vacuum, and the residue was dissolved in $4 \mathrm{~mL}$ of $100 \% \mathrm{MeOH}$. This solution was dried using nitrogen gas [34]. The extracted residue was quantified by a GC-MS-SIM (Hewlett-Packard 6890, $5973 \mathrm{~N}$ mass selective detector, Agilent, USA) equipped with a HA-1 capillary column (30 $\mathrm{m} \times 0.25 \mathrm{~mm}$ i.d. $0.25 \mu \mathrm{m}$ film thickness). Details of the GC-MS-SIM operation protocol are given in Additional file 1: Table S1. The endogenous $\mathrm{GA}_{20}$, and $\mathrm{GA}_{1}$ contents were calculated from the peak area ratios of 418/420 and 506/508, respectively (Additional file 2: Figure S1), wherein the data are provided in nanograms per gram dry weight and the data were collected from three replications.

To extract endogenous JA, we used $0.5 \mathrm{~g}$ freeze-dried plant samples. The JA was extracted according to the protocol of McCloud and Baldwin [35]. A total of $0.5 \mathrm{~g}$ dried sample was extracted with a solution of acetone and $50 \mathrm{mM}$ citric acid $(70: 30 \mathrm{v} / \mathrm{v})$, and $\left[9,10-{ }^{2} \mathrm{H}_{2}\right] 9,10$ dihydro-JA (20 ng) was added as an internal standard. The aqueous solution was then filtered and extracted with $10 \mathrm{~mL}$ of diethyl ether three times and loaded into a solid phase extraction cartridge (Sep-Pak Cartridge, Waters, USA). The cartridges were washed with $7.0 \mathrm{~mL}$ of trichloromethane and 2-propanol $(2: 1 \mathrm{v} / \mathrm{v})$. Both JAs (endogenous JA and the internal standard) were eluted with $10 \mathrm{~mL}$ of diethyl ether and acetic acid $(98: 2 \mathrm{v} / \mathrm{v})$. The sample was adjusted to $50 \mu \mathrm{L}$ with dichloromethane after evaporation of solvents and etherification of the residue with excess diazomethane. Then, the extracts were analyzed by GC-MS-SIM using the same equipment as in the GA analysis. We monitored ion fragments $(\mathrm{m} / z \mathrm{83})$ corresponding to the base peaks of JA and $\left[9,10-{ }^{2} \mathrm{H}_{2}\right]-9,10$-dihydro-JA for JA determination (Additional file 3: Figure S2). On the basis of the peak area of both JAs (standard and endogenous JA), we calculated JA content with the following formula: JA = (endogenous JA) / (standard JA) $\times$ standard amount / sample weight. All data were represented by three replications.

Endogenous free SA was measured by highperformance liquid chromatography (HPLC), and the conditions are described in Additional file 1: Table S1. Free SA was extracted based on Enyedi et al. [36] and Seskar et al. [37]. A $0.2 \mathrm{~g}$ freeze-dried sample was sequentially extracted with $90 \%$ and $100 \%$ methanol in a centrifuge $(10,000 \times g)$. Both extracts were dried in a vacuum. The dry pellets were resuspended in $2.5 \mathrm{~mL}$ of $5 \%$ trichloroacetic acid and the supernatant was partitioned with ethyl acetate/cyclopentane/isopropanol $(49.5: 49.5: 1, v / \mathrm{v})$. The top layer was transferred to a $4 \mathrm{~mL}$ vial and dried with purified $\mathrm{N}$ gas. The SA was again suspended in $1 \mathrm{~mL}$ of $70 \%$ methanol and analyzed by HPLC.

\section{Bio-image of calcium distribution}

To analyze calcium distribution in rice leaves, we applied different concentrations of $\mathrm{Si}$ with $400 \mathrm{~Bq}$ of radioisotope ${ }^{45} \mathrm{Ca}\left({ }^{45} \mathrm{CaCl}_{2}, 37 \mathrm{MBq}\right.$, NEN, USA). Thus, our experiment was composed of five different treatments, including i) DDW alone, ii) $0.5 \mathrm{mM} \mathrm{Si}+{ }^{45} \mathrm{Ca}$, iii) $1.0 \mathrm{mM} \mathrm{Si}+{ }^{45} \mathrm{Ca}$, iv) $2.0 \mathrm{mM} \mathrm{Si}+{ }^{45} \mathrm{Ca}$, and v) $4.0 \mathrm{mM}$ $\mathrm{Si}+{ }^{45} \mathrm{Ca}$. Calcium (Ca) distribution was analyzed using a bio-imaging analyzer. We removed roots from $\mathrm{Si}$ and ${ }^{45} \mathrm{Ca}$-treated rice seedlings after $48 \mathrm{~h}$, and then plant samples were dried at $85{ }^{\circ} \mathrm{C}$ for $12 \mathrm{~h}$. Dried plant samples were sealed with high-density thin film (Singsing Wrap ${ }^{\text {rix }}$ LG Co., South Korea) to prevent sample destruction or contamination. For $24 \mathrm{~h}$, plant samples were placed on cassettes (BAS-MS 2040, Fuji, Japan) containing an imaging plate (IP) that was covered with polyester. After this, reactive IP was analyzed by an IP reader (BAS-MS 1500, Fuji, Japan) and the collected data were read by an image analysis program (TINA). Finally, data were illustrated with different colors according to the concentration of ${ }^{45} \mathrm{Ca}$ [38].

\section{Determination of ${ }^{45} \mathrm{Ca}$ and urea- $^{-15} \mathrm{~N}$}

The dry weight of the plant samples was measured and samples were ground in a crucible for $\mathrm{Ca}$ isotope analysis. The crucibles were placed in an electronic furnace at $500{ }^{\circ} \mathrm{C}$ for $12 \mathrm{~h}$. Plant ash samples were mixed with a cocktail solution (Ready Organic, Beckman, USA) for a liquid scintillation counter (LSC), and radiation activity was measured by the LSC (LC 1801, Beckman, USA). To analyze nitrogen uptake, we applied urea ${ }^{15} \mathrm{~N}(2.0 \mathrm{mM}$, $4.0 \mathrm{mM}$, and $8.0 \mathrm{mM}$ ) and urea- ${ }^{15} \mathrm{~N}$ with $1.0 \mathrm{mM}$ $\mathrm{Na}_{2} \mathrm{SiO}_{3}$. Next, samples were harvested at $6 \mathrm{~h}$ and $12 \mathrm{~h}$ after exposure. Untreated rice plants (with only the application of distilled water) were used as control plants. Shoot samples were dried at $75{ }^{\circ} \mathrm{C}$ for analysis. Dried-shoot samples were ground into powder and passed through a $150 \mu \mathrm{m}$ sieve to analyze isotope ratios in a mass spectrometer (Delta V Advantage, Thermo Fisher Scientific Inc., USA). The experiment was repeated three times.

\section{Protein extraction, 2DE, and MALDI-TOF MS analysis}

Protein was extracted from the culture medium. We added a five-fold volume of acetone to the culture medium. For protein precipitation, the mixture of acetone 
and culture medium was refrigerated at $-20{ }^{\circ} \mathrm{C}$ for $2 \mathrm{~h}$. The precipitated proteins were collected by centrifuge and collected proteins were eluted by a solution containing $7 \mathrm{M}$ urea, $2 \mathrm{M}$ thiourea, 4\% (w/v) 3-[(3-cholamidopropyl) dimethyammonio]-1-propanesulfonate (CHAPS), 1\% (w/ v) dithiothreitol (DTT), $2 \%(v / v)$ pharmalyte, and $1.0 \mathrm{mM}$ benzamidine. Concentrations of protein were attained following the method of Bradford [39].

The samples were diluted with re-swelling solution (7 $\mathrm{M}$ urea, $2 \mathrm{M}$ thiourea, 2\% 3-[(3-cholamidopropy) dimethyammonio]-1-propanesulfonate (CHAPS), $1 \%$ dithiothreitol (DTT), and $1 \%$ pharmalyte) at room temperature for $12-16 \mathrm{~h}$. Isoelectric focusing (IEF) was conducted according to the manufacturer's manual (IPGphor II system, Amersham Biosciences, USA) and the conditions were $207{ }^{\circ} \mathrm{C}$ with a current limit of $50 \mathrm{~mA} /$ strip: $3 \mathrm{~h}$ at $300 \mathrm{~V}, 6 \mathrm{~h}$ at $1000 \mathrm{~V}, 3 \mathrm{~h}$ at $8000 \mathrm{~V}$ (gradient), and $24 \mathrm{~h}$ at $8000 \mathrm{~V}$. To conduct the second dimension (SDS) analysis, the individual strips were equilibrated for $15 \mathrm{~min}$ in $10 \mathrm{~mL}$ equilibration solution (6 M urea, 30\% glycerol, 2\% SDS, $0.002 \%$ bromophenol blue, and $50 \mathrm{mM}$ Tris $\mathrm{pH} 8.8$ ) containing $1 \% w / v$ DTT and subsequently for $15 \mathrm{~min}$ in $10 \mathrm{~mL}$ equilibration buffer containing $4.5 \% \mathrm{w} / \mathrm{v}$ iodoacetamide.

Proteins were visualized by silver staining [40]. The gels were fixed in fixing solution (40\% ethanol and 10\% acetic acid) overnight for silver staining. The gels were consecutively washed with $30 \%$ ethanol for $20 \mathrm{~min}, 20 \%$ ethanol for $20 \mathrm{~min}$, and DDW for $20 \mathrm{~min}$, and then were consecutively sensitized, developed, and neutralized. Detailed information is described in Carpentier et al. [41]. Stained gels were scanned using the Duoscan T1200 (Agfa, USA) and images were analyzed by PDQuest software (version 7.0, BioRad) for quantification. Individual spot quantity was normalized by total valid spots, and spot detection was realized without spot editing. The spots were quantified using the \% volume criterion, and significantly different spots (two-fold difference) were used for identification.

Each protein was analyzed by Ettan MALDI-TOF (Amersham Biosciences, UK) for identification. Protein fragments were evaporated at $337 \mathrm{~nm}$ using an $\mathrm{N}_{2}$ laser and were accelerated by a $20 \mathrm{kV}$ injection pulse. The mass spectrum of each spot was measured by accumulated peaks, which were collected by $300 \mathrm{~nm}$ laser shots. The ion peak $\mathrm{m} / \mathrm{z}(842.510,2211.4016)$ was used as the standard peak for mass spectrum, and we used Profound (http://prowl.rockefeller.edu/), which was developed by The Rockefeller University, for protein identification.

\section{RNA extraction and RT-PCR analysis}

The total RNA was extracted from plant samples using an RNeasy Plant Extraction Mini Kit (Qiagen) following the manufacturer's instructions. For ReverseTranscription (RT)-PCR, complementary DNA was synthesized using an RT Kit (Solsent, Korea). All the reactions were performed according to the manufacturer's instructions. RT-PCR was conducted for evaluation of mRNA expression of G-6-P and IMP3 [42]. OsUBI was used as a control. The primers for RT-PCR are mentioned in Additional file 4: Table S2.

\section{Statistical analysis}

To evaluate quantitative differences in radioisotope ${ }^{45} \mathrm{Ca}$ content and plant hormones, all data were statistically analyzed for standard errors using Sigma Plot Software (2004). A two-way analysis of variance (ANOVA) was performed to determine significant differences among results (SAS release 9.1; SAS, Gary, NC, USA), and differences between mean values among treatments were compared using Duncan's multiple range test (DMRT) at $P<0.05$ and $P<0.01$. All the analyses were performed in triplicate.

\section{Results}

Influence of mineral uptake after Si treatment

To evaluate mineral uptake in rice plants, we measured several mineral ratios after Si application (0.5, 1.0, 2.0, and $4.0 \mathrm{mM}$ ) in hydroponically grown rice plants. The nitrogen $(\mathrm{N})$ and potassium $(\mathrm{K})$ ratio showed a decreasing pattern as compared to the control, however, it was not statistically different $(P<0.05)$ (Table 1$)$. The phosphorus $(\mathrm{P})$ ratio in $\mathrm{Si}$-applied plants revealed a slight decrease in the pattern, except in the $1.0 \mathrm{mM}$ Si treatment. Conversely, the magnesium $(\mathrm{Mg})$ ratio was significantly increased in the 1.0, 2.0, and $4.0 \mathrm{mM} \mathrm{Si}$ treatments in comparison to the control, but no difference was observed in the $0.5 \mathrm{mM}$ Si treatment as compared to the control (Table 1). The calcium $(\mathrm{Ca})$ ratio decreased approximately to $11.8 \%(0.5 \mathrm{mM}$ and $4.0 \mathrm{mM})$ from $15.8 \%$ $(1.0 \mathrm{mM})$ in all concentrations of $\mathrm{Si}$ treatments. The $\mathrm{Si}$ content was absolutely increased in a dose-dependent manner when $\mathrm{Si}$ was applied to plants. This supports the idea that changes in mineral contents were triggered by the Si applications (Table 1).

\section{Influence on endogenous hormone levels after $\mathrm{Si}$ treatment}

Plant hormones are known to induce various physiological and biochemical responses at very low concentrations [33]. For this reason, we analyzed endogenous GA and JA levels after $\mathrm{Si}$ application. Bioactive $\mathrm{GA}_{1}$ concentration was significantly increased with $\mathrm{Si}$ application $(0.5,1.0$, 2.0 , and $4.0 \mathrm{mM})$ for all exposure times $(6 \mathrm{~h}, 12 \mathrm{~h}$, and $24 \mathrm{~h}$ ) as compared to that of the control (Fig. 1). In particular, comparison of $\mathrm{GA}_{1}$ levels among $\mathrm{Si}$ treatments revealed that it was significantly higher $(P<0.01)$ in the $1.0 \mathrm{mM}$ Si treatment as compared to that of the remaining 
Table 1 Effect of exogenously applied Si on mineral content in rice plants. Si was applied in hydroponic solution (Yoshida solution) for $24 \mathrm{~h}$ and then samples were collected for analysis

\begin{tabular}{lllllll}
\hline Treatments & T-N (\%) & P (\%) & K (\%) & Ca (\%) & Mg (\%) & Si (ppm) \\
\hline Control & $1.33 \pm 0.10 \mathrm{a}$ & $0.24 \pm 0.01 \mathrm{a}$ & $1.95 \pm 0.28 \mathrm{a}$ & $0.19 \pm 0.11 \mathrm{a}$ & $0.08 \pm 0.01 \mathrm{~b}$ & $3007 \pm 12.3 \mathrm{~b}$ \\
$0.5 \mathrm{mM} \mathrm{Si}$ & $1.34 \pm 0.12 \mathrm{a}$ & $0.22 \pm 0.09 \mathrm{ab}$ & $1.93 \pm 0.31 \mathrm{a}$ & $0.17 \pm 0.21 \mathrm{ab}$ & $0.09 \pm 0.01 \mathrm{~b}$ & $3155 \pm 8.91 \mathrm{ab}$ \\
$1.0 \mathrm{mM} \mathrm{Si}$ & $1.28 \pm 0.27 \mathrm{a}$ & $0.25 \pm 0.1 \mathrm{a}$ & $1.92 \pm 0.13 \mathrm{a}$ & $0.16 \pm 0.15 \mathrm{ab}$ & $0.11 \pm 0.03 \mathrm{ab}$ & $3402 \pm 13.4 \mathrm{a}$ \\
$2.0 \mathrm{mM} \mathrm{Si}$ & $1.27 \pm 0.0 .21 \mathrm{a}$ & $0.21 \pm 0.1 \mathrm{~b}$ & $1.92 \pm 0.42 \mathrm{a}$ & $0.15 \pm 0.02 \mathrm{~b}$ & $0.10 \pm 0.08 \mathrm{ab}$ & $3440 \pm 21.2 \mathrm{a}$ \\
$4.0 \mathrm{mM} \mathrm{Si}$ & $1.27 \pm 0.13 \mathrm{a}$ & $0.22 \pm 0.1 \mathrm{ab}$ & $1.90 \pm 0.23 \mathrm{a}$ & $0.17 \pm 0.06 \mathrm{ab}$ & $0.12 \pm 0.02 \mathrm{a}$ & $3431 \pm 11.49 \mathrm{a}$ \\
\hline
\end{tabular}

Values with \pm shows the standard error of the mean of three replications. Different letters in each column indicate statistically significant differences $(P<0.05)$ among treatments by Duncan's Multiple Range Test (DMRT)

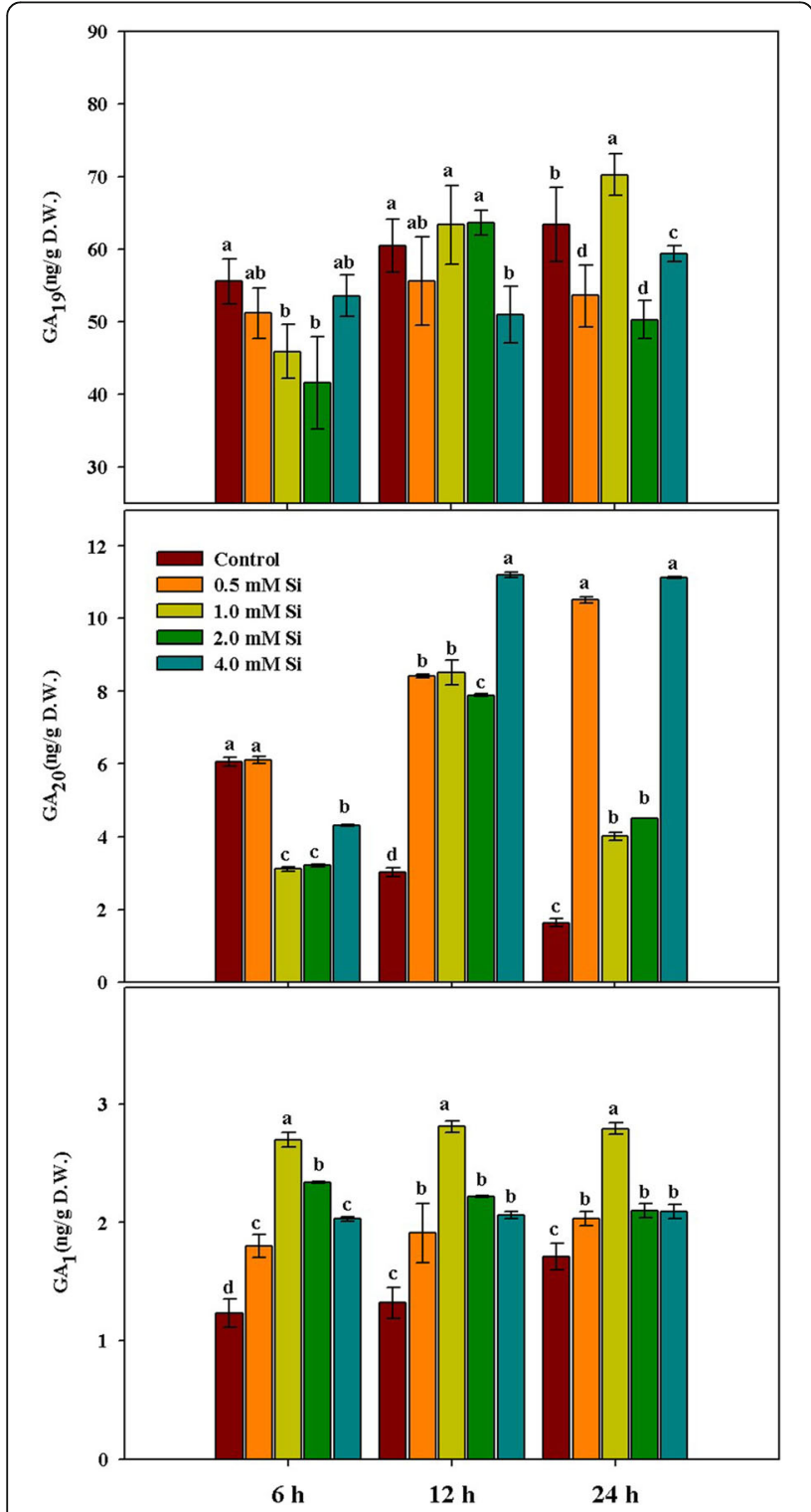

Fig. 1 Changes in the levels of gibberellin $\left(G A_{1}\right)$ and its precursors $\left(G_{19}\right.$ and $\left.G A_{20}\right)$ in rice plants in response to different concentrations of Si. The different letter(s) indicates significant differences at $P<0.05$ according to Duncan's multiple range test (DMRT). Each bar shows the standard error of the means of three replications
Si treatments (Fig. 1). Concentrations of $\mathrm{GA}_{20}$ also exhibited higher levels with $\mathrm{Si}$ application as compared to the control at $12 \mathrm{~h}$ and $24 \mathrm{~h}$ exposure, whereas $\mathrm{GA}_{20}$ content was significantly decreased following $\mathrm{Si}$ application, except for the $0.5 \mathrm{mM} \mathrm{Si}$ treatment, in comparison with that of the control at $6 \mathrm{~h}$ exposure (Fig. 1). Endogenous hormone JA also exhibited a similar pattern as $\mathrm{GA}_{1}$. Endogenous JA levels were significantly increased at all concentrations of $\mathrm{Si}$ application as compared to that of the control, and this tendency was consistently observed in all periods (Fig. 2). Comparison of JA content among Si treatments revealed a maximum value with $1.0 \mathrm{mM} \mathrm{Si}$ treatment, whereas $0.5 \mathrm{mM} \mathrm{Si}$ induced the minimum value in all time periods. There were no differences in response between $2.0 \mathrm{mM} \mathrm{Si}$ and $4.0 \mathrm{mM}$ Si treatments at 6 and $12 \mathrm{~h}$ exposure (Fig. 2). Similarly, increased hormone patterns following $\mathrm{Si}$ application were detected. The $1.0 \mathrm{mM}$ Si treatment exhibited highly increased endogenous free SA content as compared to that of the control and other concentrations of Si treatments (Fig. 3). Comparison of free SA content among different $\mathrm{Si}$ treatments revealed that the maximum content was observed with $1.0 \mathrm{mM} \mathrm{Si}$ application, while $0.5 \mathrm{mM}$ $\mathrm{Si}$ and $2.0 \mathrm{mM} \mathrm{Si}$ resulted in similar SA levels (Fig. 3). Low free SA levels were detected following the $4.0 \mathrm{mM} \mathrm{Si}$ treatment for all periods, although it remained at a higher level than that of the control (Fig. 3).

\section{Distribution and concentration of $\mathrm{ca}$ in rice leaves}

In our previous experiment, we found that Ca uptake in rice plants decreased with increasing concentrations of Si. To identify Ca movement and uptake, we directly applied radioisotope ${ }^{45} \mathrm{Ca}$ during the application of varying Si concentrations $(0.5,1.0,2.0$, and $4.0 \mathrm{mM})$ to hydroponically grown rice plants. The radioisotope data are shown in Fig. 4. According to the image for ${ }^{45} \mathrm{Ca}$ accumulation and localization, the third leaf showed high ${ }^{45} \mathrm{Ca}$ accumulation as compared to the first and second leaf, and this pattern was consistent in the control and all Si treatments (Fig. 4a). In case of the third leaf, however, ${ }^{45} \mathrm{Ca}$ accumulation was highly reduced in Si-treated plants as compared to the control. Additionally, ${ }^{45} \mathrm{Ca}$ accumulation in the third leaf was gradually reduced with 


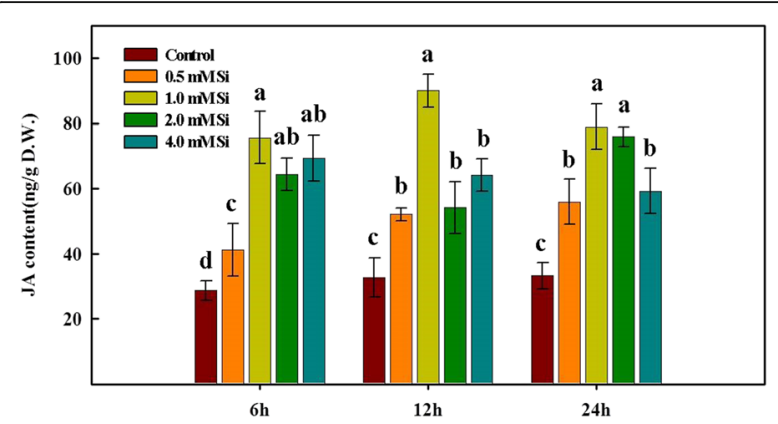

Fig. 2 Regulation of endogenous jasmonic acid (JA) levels in rice plants after the exogenous application of different concentrations of Si. The different letter(s) indicate significant differences at $P<0.05$ according to Duncan's multiple range test (DMRT). Each bar shows the standard error of the means of three replications

increasing $\mathrm{Si}$ concentration (Fig. 4a). The content of radioisotope ${ }^{45} \mathrm{Ca}$ was significantly inhibited (approximately 1.8 - to 2.0-fold reduction in comparison to the control) by all exogenous $\mathrm{Si}$ applications (Fig. 4b).

\section{Effects of Si on $\mathrm{N}$ uptake and distribution in rice leaves}

We applied different concentrations of urea- ${ }^{15} \mathrm{~N}(2.0 \mathrm{mM}$, $4.0 \mathrm{mM}$, and $8.0 \mathrm{mM}$ ) and urea- ${ }^{15} \mathrm{~N}$ with $1.0 \mathrm{mM} \mathrm{Si}$ for $12 \mathrm{~h}$ and the samples were harvested twice (6 h and $12 \mathrm{~h}$ ). The ${ }^{15} \mathrm{~N}$ ratios are shown in Fig. 5. In the 6 h treatment, the ${ }^{15} \mathrm{~N}$ ratio was increased in all treatments in comparison with the control. When we applied ${ }^{15} \mathrm{~N}(2.0,4.0$, and $8.0 \mathrm{mM})$ with $1.0 \mathrm{mM} \mathrm{Si}$, the ${ }^{15} \mathrm{~N}$ ratio was reduced as compared to ${ }^{15} \mathrm{~N}$ treatment alone (Fig. $5 \mathrm{a}$ ). In the case of the $12 \mathrm{~h}$ treatment, the same trend and effect were observed. The ${ }^{15} \mathrm{~N}$ ratio was increased in ${ }^{15} \mathrm{~N}$-supplemented rice plants as compared to the control, whereas the ${ }^{15} \mathrm{~N}$ ratio was slightly decreased in the ${ }^{15} \mathrm{~N}$ with Si-treated rice plants in comparison to plants treated with ${ }^{15} \mathrm{~N}$ alone (Fig. 5b).

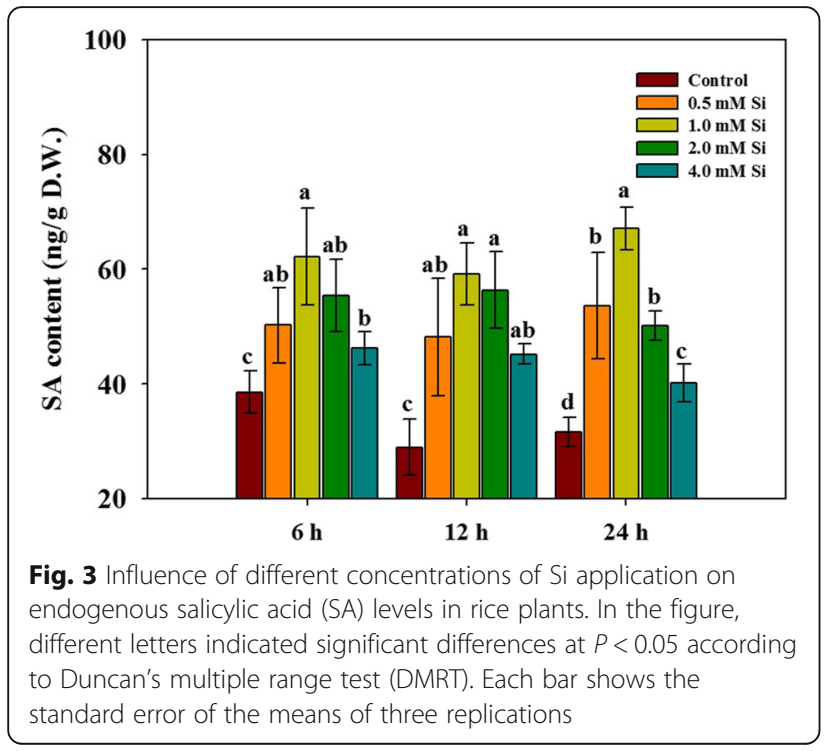

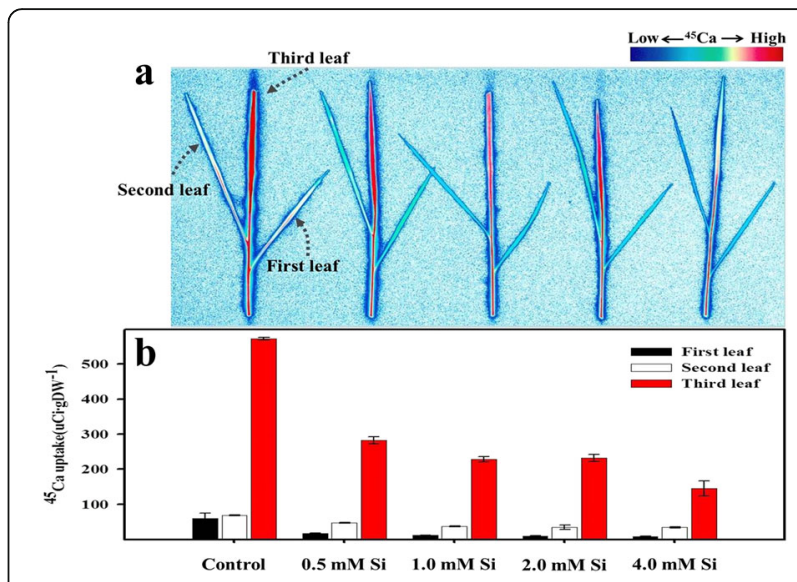

Fig. 4 Changes in calcium uptake under Si application in rice plants. In Figure (a), the color closest to red indicates higher uptake of ${ }^{45} \mathrm{Ca}$, whereas the color closest to blue indicates lower uptake of ${ }^{45} \mathrm{Ca}$. Figure (b) shows quantities of ${ }^{45} \mathrm{Ca}$ at different leaf positions. Each bar shows the standard error of the means of three replications

\section{Influence of Si application with nitrogen and calcium} fertilizer on mineral uptake

Our previous results showed that $\mathrm{N}$ and $\mathrm{Ca}$ uptake were significantly decreased by $\mathrm{Si}$ application. However, the previous study was conducted under restricted environmental conditions (only ${ }^{15} \mathrm{~N}$ and ${ }^{45} \mathrm{Ca}$ supplied). Thus, we conducted an analysis of mineral uptake in rice plants after a combination of nitrogen $\left(\mathrm{NH}_{4} \mathrm{NO}_{3}\right)$ and calcium fertilizer $\left(\mathrm{CaCl}_{2}\right)$ treatments with $\mathrm{Si}$ (Additional file 5: Table S3). Total nitrogen (T-N) content was significantly increased in the $\mathrm{NH}_{4} \mathrm{NO}_{3}$ treatment in comparison to that of the control; however, it was suppressed by approximately $10.6 \%$ by the addition of $1.0 \mathrm{mM}$ Si (Additional file 5: Table S3). Conversely, T-N content did not exhibit a statistically significant difference among independent and combination treatments of $\mathrm{CaCl}_{2}$ and $\mathrm{Si}$ (Additional file 5: Table S3). With $\mathrm{NH}_{4} \mathrm{NO}_{3}$ treatment, other mineral contents, such as those of $\mathrm{P}, \mathrm{K}$, $\mathrm{Ca}$, and $\mathrm{Mg}$, did not exhibit any difference as compared to the control, whereas $\mathrm{Si}$ concentration significantly increased in $\mathrm{NH}_{4} \mathrm{NO}_{3}$ with $\mathrm{Si}$ application, as expected (Additional file 5: Table S3). In the $\mathrm{CaCl}_{2}$ and $\mathrm{Si}$ combination treatment, $\mathrm{Ca}$ uptake was significantly inhibited by $1.0 \mathrm{mM}$ Si supplement in comparison with that of $\mathrm{CaCl}_{2}$ alone (Additional file 5: Table S3). Except for Si concentrations, we did not observe statistically increased or decreased mineral uptake among any of the treatments (Additional file 5: Table S3).

\section{Influence of Si on protein expression}

$\mathrm{Si}$ application to rice plants inhibited $\mathrm{N}$ and $\mathrm{Ca}$ uptake as well as increased endogenous hormones. Thus, we conducted 2-DE gel analysis to determine the difference in protein expression between non-Si treatment and 

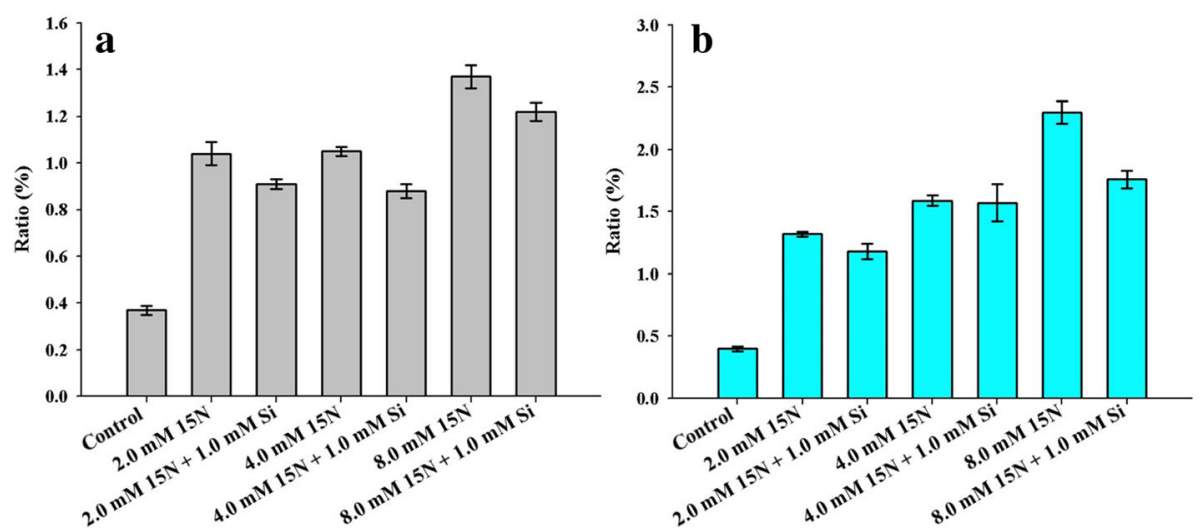

Fig. 5 Effects of Si application on nitrogen uptake in rice plants. Figure (a) shows the ${ }^{15} \mathrm{~N}$ ratio in rice plants at $6 \mathrm{~h}$ exposure and Figure (b) indicates the ${ }^{15} \mathrm{~N}$ ratio in rice plants at $12 \mathrm{~h}$ exposure. Each bar shows the standard error of the means of three replications

1.0 mM Si treatment. Different protein expressions are shown in Fig. 6. According to our results, seven kinds of 2 -DE spots exhibited significant $(P<0.01)$ differences between Si-treated and Si-untreated plants (Fig. 6). Among the seven protein spots, four were upregulated in Sitreated plants (Spot No: 1022, 2106, 2607, and 5011), and the other three were downregulated (Spot No: 2204, 2605, and 4011) (Table 2). All spots' (1022, 2106, 2204, $2605,2607,4011$, and 5011) information is very well described in Table 2. Among these seven spots, spot 2607 was significantly upregulated by $1.0 \mathrm{mM} \mathrm{Si}$ treatment, and it was identified as importin alpha $1 \mathrm{~b}$ protein. Conversely, spot 2605, glucose-6-phosphate isomerase, was significantly downregulated by $1.0 \mathrm{mM} \mathrm{Si}$ treatment and was significantly higher across treatments (Table 2).

\section{Influence of Si on expression of importin and the G-6-P gene}

We found different protein expressions after Si application. Thus, we compared the mRNA expression of IMP3 and G-6-P genes in the control and $1.0 \mathrm{mM}$ Si-treated plants by RT-PCR analysis. The mRNA expression of
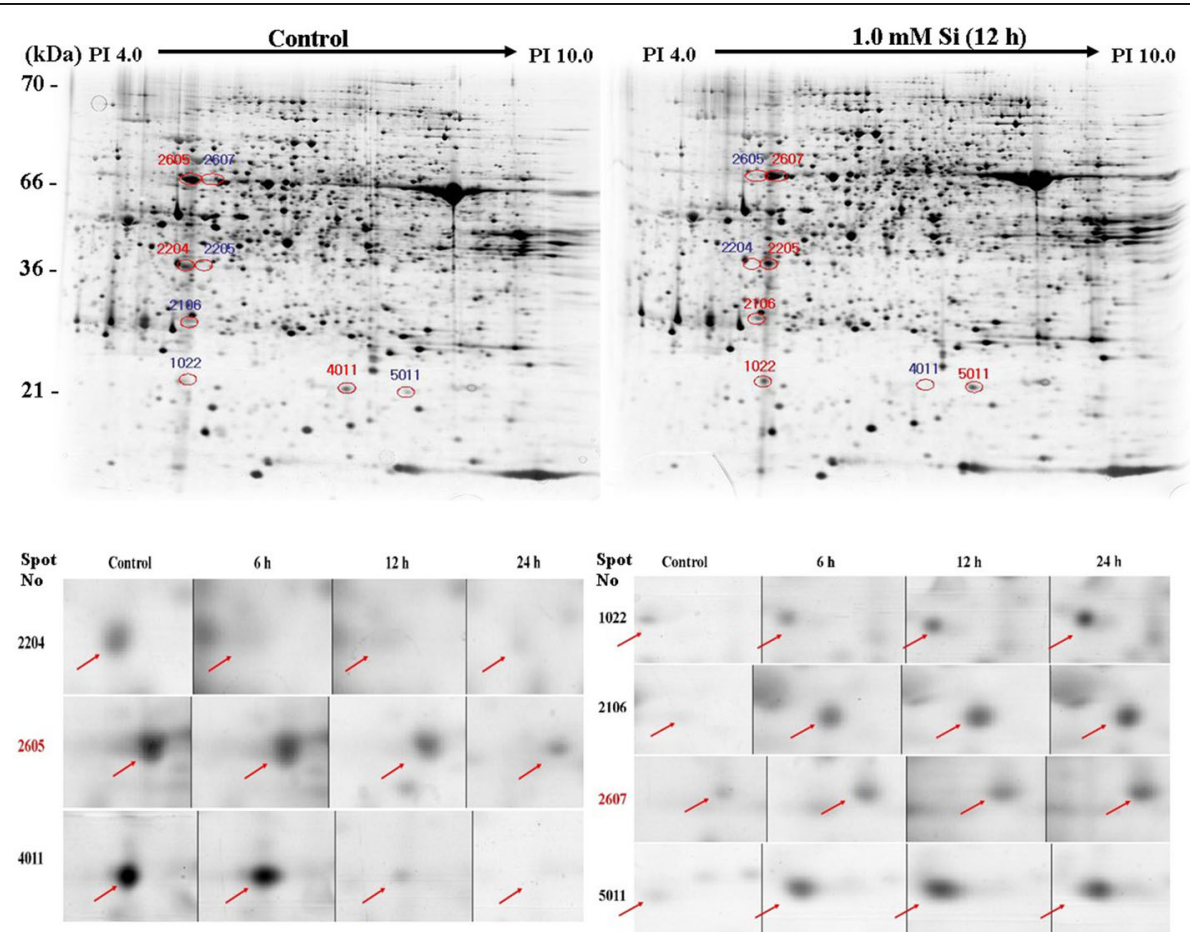

Fig. 6 Expressions of protein levels in rice plants after exposure to short-term Si application. In the figure, red circles reveal upregulated protein spots as compared to that of the control, and blue circles indicate downregulated protein spots relative to that of the control 
Table 2 Different protein expression between Si treated and Si untreated plant. Protein information was identified by mass and plant samples harvested at $12 \mathrm{~h}$ after Si application

\begin{tabular}{lllllll}
\hline Spot No & Protein name & Exp MW/PI & Theo MW/PI & SC (\%) & Expression Pattern & Accession No \\
\hline 1022 & Rieske Fe-S precursor protein & $21.09 / 4.93$ & $24.21 / 9.2$ & 22 & up & gi|50,508,582 \\
2106 & Putative thioredoxin-like protein CDSP32 & $29.26 / 5.01$ & $32.48 / 6.3$ & 34 & up & gi|34,901,636 \\
2204 & Putative Ser/The protein Phosphatase & $36.54 / 5.00$ & $35.26 / 5.1$ & 19 & down & gi|34,911,376 \\
2605 & Putative glucose-6-phosphate isomerase & $64.17 / 5.01$ & $68.86 / 5.7$ & 20 & down & gi|50,900,276 \\
2607 & Importin alpha 1b & $62.30 / 5.03$ & $59.09 / 5.2$ & 26 & up & gi|6,682,927 \\
4011 & unnamed protein product & $21.08 / 5.56$ & $15.90 / 5.7$ & 25 & down & gi|34,895,594 \\
5011 & Rieske Fe-S precursor protein & $20.89 / 6.20$ & $24.21 / 9.2$ & 17 & up & gi|50,508,582
\end{tabular}

Expression pattern indicated a comparison with control. Accession number (GI number), MW Molecular weight, $P I$ Isoeletronic point, SC Sequence coverage, Theo Theoretical value

IMP3 was increased in Si-treated rice plants as compared to that of the control (Fig. 7). Conversely, mRNA expression of G-6-P exhibited a decreasing pattern in comparison with that of the control; in particular, mRNA expression level gradually decreased with increasing Si exposure period (Fig. 7).

\section{Discussion}

Exogenous $\mathrm{Si}$ application has been reported to confer ameliorative potential to the growth and physiology of a wide array of crop plants. Several studies have shown beneficial $\mathrm{Si}$ effects such as intervention in oxidative stress, phytohormonal changes, gene expression, and resistance against abiotic and biotic stresses $[10,11,25,30$, 31, 43, 44]. Recently, Deshmukh et al. [45] reported the existence of a $\mathrm{Si}$ uptake gene in dicotyledonous plants. The gene was located in aquaporin, and thus it reached the plant cell by passing through aquaporin in water [45]. Therefore, uptake of $\mathrm{Si}$ can induce various physiological responses. Our first experiments on $\mathrm{Si}$ focused on the effects of $\mathrm{Si}$ on plant growth and crop yield. According to Datnoff et al. [46], Japanese farmers increased rice productivity ( $6 \mathrm{t} / \mathrm{ha}$ ) by integrating nutrient management, including Si fertilization.

Essential elements, such as $\mathrm{N}, \mathrm{P}, \mathrm{K}, \mathrm{Mg}$, and $\mathrm{Ca}$, are known to be key regulators of plant life. Nitrogen $(\mathrm{N})$ is an essential macronutrient and is a component of amino acid, amides, proteins, nucleic acids, and nucleotides, as well as a constituent of nitric oxide (NO), which is a highly reactive free radical that is involved in the immune system in animal and plant cells [47-49]. Therefore, under serious $\mathrm{N}$ deficiencies, plants exhibit chlorosis (yellowing of the leaves) owing to their inability to produce amino acids and other metabolites that are essential for metabolic processes [50-52]. In addition, $\mathrm{N}$ is involved in physiological responses, such as the growth of stem internodes, leaf expansion, and acceleration of cell division [23]. In particular, rice plants quickly respond to exogenous $\mathrm{N}$ sources in soil. Thus, rice plants can induce shoot growth. Si is absorbed by low-silicon genes (OsLsi1, OsLsi2, HvLsi1, and HvLsi2), which are located on both sides of the Casparian strip in rice and barley roots, and $\mathrm{Si}$ can be transferred to the shoots through the xylem [2].

$\mathrm{N}$ concentration did not exhibit a statistical difference with $\mathrm{Si}$ application alone $(0.5 \mathrm{mM}, 1.0 \mathrm{mM}, 2.0 \mathrm{mM}$, and $4.0 \mathrm{mM}$ ) as compared to that of the control; however, the ratio of urea- ${ }^{15} \mathrm{~N}$ showed an inhibition pattern when $\mathrm{N}$ was applied with $1.0 \mathrm{mM} \mathrm{Si}$. Thus, our results showed that $\mathrm{Si}$ application could inhibit $\mathrm{N}$ uptake in rice plants. However, our findings were different from those of previous studies. Cho et al. [53] analyzed nutrient recovery rates after they applied ${ }^{15} \mathrm{~N}$ and purified Si fertilizer to rice plants and found increased ${ }^{15} \mathrm{~N}$ uptake at higher concentrations of $\mathrm{Si}$ supplementation in rice plants. Jawahar and Vaiyapuri, [54] also reported that $\mathrm{N}$ uptake was increased when they
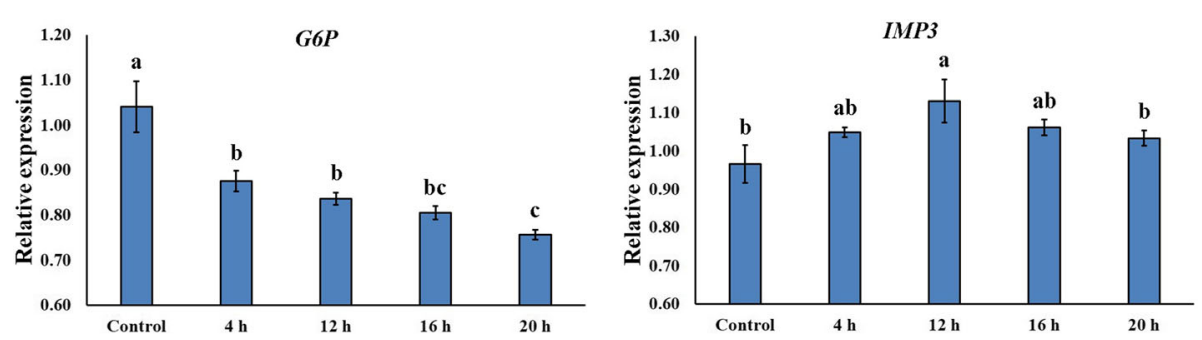

Fig. 7 The mRNA expression of G6P and IMP3 in rice plants after Si application. Plant samples were collected at $4 \mathrm{~h}, 12 \mathrm{~h}, 16 \mathrm{~h}$ and $20 \mathrm{~h}$ after Si treatment. In the figure, a vertical bar means standard \pm standard deviation $(n=3)$ 
applied more Si fertilizer to rice plants. However, both experiments mentioned above were conducted under field conditions. In addition, data were collected over long periods after Si fertilizer application to the rice (panicle initiation stage and harvesting stage) [53]. In contrast, we applied ${ }^{15} \mathrm{~N}$ with $1.0 \mathrm{mM}$ Si simultaneously and then collected plant samples at $12 \mathrm{~h}$ and $24 \mathrm{~h}$ after treatment. This difference (different Si applications) resulted in different $\mathrm{N}$ uptake. Another possibility is that $\mathrm{N}$ uptake decreases with Si supplement at short exposure times (12 h and $24 \mathrm{~h}$ ), but increases when rice plants are exposed to $\mathrm{Si}$ for long periods (30 days and 60 days). To acquire more evidence, additional experiments are needed in which purified $\mathrm{Si}$ is applied with and without ${ }^{15} \mathrm{~N}$ to rice plants and $\mathrm{N}$ uptake is traced for a long period.

According to our results, Ca uptake was significantly inhibited by $\mathrm{Si}$ application. This could be attributed to the fact that $\mathrm{Si}$ administered the stress cofactors, whereas $\mathrm{Ca}$ oscillation has mostly been credited to highstress conditions [55]. The same results were observed by $\mathrm{Ma}$ and Takahashi [56]. They applied $100 \mathrm{ppm}$ of $\mathrm{SiO}_{2}$ as silicic acid to hydroponically grown rice plants for $72 \mathrm{~h}$ and then harvested plant samples for nutrient analysis. They found that $\mathrm{Ca}$ uptake was significantly decreased (approximately 39\%) by Si supplementation as compared to that of non-supplemented plants. However, different results were reported by other researchers [55, 57, 58]. According to Kaya et al. [57], Ca contents in leaves did not exhibit differences between control and Si-treated plants when $\mathrm{Si}$ was applied to maize grown under well-watered conditions, whereas increased $\mathrm{Ca}$ content was observed in Si-treated maize grown under water-limiting conditions as compared to non-Si-treated maize. In short, $\mathrm{Ca}$ uptake was increased with $\mathrm{Si}$ $\left(\mathrm{K}_{2} \mathrm{SiO}_{3}\right)$ application to a relatively salt-tolerant cultivar under normal and salinity stress conditions $[55,58]$.

Plant hormones, such as GA and JA, are known to be signal molecules for various physiological responses at very low concentrations [11, 59]. GA is biosynthesized from trans-geranylgeranyl diphosphate in chloroplasts and then moved into the endoplasmic reticulum and cytosol. In particular, bioactive $\mathrm{GA}_{1}$ and $\mathrm{GA}_{4}$ are synthesized by two different pathways in the cytosol [60]. According to our results, bioactive $\mathrm{GA}_{1}$ concentration was significantly increased in Si-treated rice plants at all periods; however, $\mathrm{GA}_{20}$ content was increased at $12 \mathrm{~h}$ and $24 \mathrm{~h}$ after Si treatment. In particular, $\mathrm{GA}_{20}$ concentration exhibited a decreased pattern relative to that of the control. Focusing on the change in bioactive $G_{1}$, we showed only $G_{20}$ and $\mathrm{GA}_{1}$ data; however, we also analyzed the precursors of $\mathrm{GA}_{20}\left(\mathrm{GA}_{19}, \mathrm{GA}_{53}\right.$, and $\left.\mathrm{GA}_{12}\right)$. $\mathrm{GA}_{19}$ content exhibited an increase (50 ng to $60 \mathrm{ng}$, data not shown) relative to that of the control. Therefore, the difference between bioactive $\mathrm{GA}_{1}$ and non-active $\mathrm{GA}_{20}$ in control plants was probably induced by the activities of different types of enzymes. Similar results were also reported when ABA-treated oriental melons and their controls were compared. It was found that $\mathrm{GA}_{20}$ concentration gradually decreased, but $\mathrm{GA}_{19}$ concentration had an opposite and increasing trend in accumulation during the application period [61]. Normally, increased bioactive Gas $\left(\mathrm{GA}_{1}\right.$ and $\left.\mathrm{GA}_{4}\right)$ contributes to stress mitigation (salinity stress: [8]; waterlogging: [62]), cell elongation during submergence [63] and root elongation [64]. Based on previous studies, therefore, we can hypothesize that $\mathrm{Si}$ application to rice can induce physiological or biochemical changes. Similar conclusions were also drawn by Kim et al. [11], where Si application significantly influenced endogenous plant hormones under either normal or stress conditions induced by salinity, heavy metals, and drought.

Another plant hormone, JA, can also trigger diverse physiological responses, such as floral development [65], senescence induction [66], potato tuberization [67], biotic stress amelioration [68], and growth inhibition [69]. In particular, JA plays an important role in plant defenses against insect herbivory and fungi [11]. Thus, JA can induce various defense proteins when plants are exposed to insect herbivory $[29,70]$. When different concentrations of $\mathrm{Si}$ were applied to rice plants, endogenous JA content was significantly increased in all Si-treated plants as compared to that of non-Si treated plants. The way in which rice plants take up Si from soil to shoot has already been identified $[7,13]$. Absorbed Si in rice plants can be immediately deposited in the leaf blade $(2.5 \mu \mathrm{m})$ of rice and observed in a Si-cuticle double layer [71]. Therefore, we assumed that $\mathrm{Si}$ supplementation confers mechanical strength to rice plants and also induces a similar innate immunity against biotic stress factors, such as insects. Thus, endogenous JA contents were significantly increased in Si-applied rice plants. Similar results were reported by Kim et al. [72, 74]. They reported that JA levels were significantly increased in $\mathrm{Si}$-applied rice plants under normal conditions (non-stress conditions); however, when they supplied mechanical wounding stress to rice plants, JA levels were strongly inhibited in Si-treated plants in comparison with that of the control. In addition, differences were observed at the genetic level that involved the JA biosynthesis pathway as compared to that of the control. In addition, JA enrichment was observed under stressful conditions [8, 11, 73, 74]; thus, our result assumed that exogenously applied $\mathrm{Si}$ could enhance resistance to biotic or abiotic stress via upregulated JA because high levels of JA could induce increased antioxidant (catalase: CAT) activity or decreased non-enzymatic antioxidant activity (malondialdehyde: MDA) [4, 25].

$\mathrm{Si}$ application can induce changes in phytohormones, such as $\mathrm{GA}_{1}$ and JA; thus, we evaluated $\mathrm{Si}$ effect on changes in proteins. Through our experiment, up- or 
down-regulated spots were identified. Among upregulated spots, spot 2607 was significantly upregulated by $\mathrm{Si}$ application and was identified as importin alpha $1 \mathrm{~b}$. Importin alpha protein binds to the nuclear localization signals (NLS) in the cytoplasm [75]. According to Jiang et al. [75], rice importin alpha 1 specifically binds to TNLS and O2-NLS proteins, whereas Yamamoto and Deng [76] show binding to typical classes of NLS in Arabidopsis [77]. Thus, tissue-specific expression of importin could regulate protein importation into the nucleus and could participate in NLS-selective recognition [75]. Si-applied rice plants exhibited downregulated proteins; in particular, glucose-6-phosphate isomerase $(G 6 P)$ was significantly downregulated. $G 6 P$ and D-fructose 6phosphate $(F 6 P)$ are catalyzed from phosphoglucose isomerase, which is the second step in glycolysis as well as gluconeogenesis and the glycosylation of protein [78]. The effects on G6P and F6P showed that these are significantly downregulated by $\mathrm{Si}$ supplementation during glycolysis [79]. This is in agreement with the previous findings. In order to understand the underlying mechanism of $\mathrm{Si}$ application, further in-depth molecular studies are necessary to understand the key interactions.

\section{Conclusions}

In summary, $\mathrm{Si}$ application to rice plants induced several physiological changes. First, Si-applied rice plants significantly inhibited Ca uptake. In particular, Ca uptake was significantly inhibited in relatively young leaves (third leaf) in comparison to older leaves (first leaf) and this phenomenon was confirmed by uptake of radioisotope ${ }^{45} \mathrm{Ca}$. Second, $\mathrm{Si}$ application could induce higher levels of bioactive $\mathrm{GA}_{1}$, JA, and SA. Thus, we assumed that endogenous hormone change would participate in various physiological responses, especially with increased hormones involved in the mitigation of abiotic stress. Third, Si treatment affected the expression of several proteins; in particular, importin alpha $1 \mathrm{~b}$ protein was upregulated and G6P protein was downregulated by Si supplementation. Thus, we hypothesize that $\mathrm{Si}$ was able to regulate protein importation into the nucleus and also might be involved in regulation of G6P and F6P during glycolysis of rice plants. The current study will serve as the basis for further in-depth studies on the physio-chemo-proteomics of $\mathrm{Si}$, while focusing on flooding and salinity stresses.

\section{Additional files}

Additional file 1: Table S1. Conditions of GC-MS-SIM and HPLC for analyzing the plant hormones. (DOCX $14 \mathrm{~kb}$ )

Additional file 2: Figure S1. Information for GC-MS-SIM chromatogram. Bioactive $G A_{1}$ showed two different ion values $\left[{ }^{2} \mathrm{H}_{2} \mathrm{GA}_{1}\right.$ (508 ion) was used as the standard and $\mathrm{GA}_{1}$ (506 ion) was used as endogenous $\mathrm{GA}_{1}$ ]. (DOCX $14 \mathrm{~kb})$
Additional file 3: Figure S2. Information for GC-MS-SIM chromatogram Me-JA retention time was $18: 46$ and internal standard $\left(9,10-{ }^{2} \mathrm{H}_{2} \mathrm{JA}\right)$ retention time was 18:70. (DOCX $15 \mathrm{~kb}$ )

Additional file 4: Table S2. The primers used for real-time PCR. (JPEG $107 \mathrm{~kb}$ )

Additional file 5: Table S3. Influence of mineral uptake in rice plants after lone nutrient treatment or each nutrient with Si application. All plant samples were exposed to the nutrient alone or in combination with $\mathrm{Si}$ for $24 \mathrm{~h}$ and then samples were analyzed for mineral uptake. (JPEG $107 \mathrm{~kb})$

\section{Abbreviations}

APX: Ascorbate peroxidase; Ca: Calcium; CAT: Catalase; DDW: Double-distilled water; F6P: D-fructose 6-phosphate; G6P: Glucose-6-phosphate isomerase;

GA: Gibberellins; Imp3: Importin alpha-1 b; IP: Image plate; JA: Jasmonic acid; MDA: Malondialdehyde; Mg: Magnesium; N: Nitrogen; NLS: Nuclear localization signal; NO: Nitric oxide; SA: Salicylic acid; Si: Silicon;

SOD: Superoxide dismutase; T-N: Total nitrogen

\section{Acknowledgments}

Not applicable

\section{Funding}

This work was supported by the Korea Institute of Planning and Evaluation for Technology in Food, Agriculture, Forestry and Fisheries (IPET) through the Agriculture, Food and Rural Affairs Research Center Support Program, funded by the Ministry of Agriculture, Food and Rural Affairs (MAFRA) (716001-7). This research was also supported by the Basic Science Research Program through the National Research Foundation of Korea (NRF) funded by the Ministry of Education (2017R1D1A3B03030917). All these funding's contributed in the experimental design and data analysis (2DE, MALDI-TOF MS analysis, hormone analysis and radioisotope elements uptake). Moreover, we used all the funding for data interpretation, English editing and writing the manuscript.

\section{Availability of data and materials}

The datasets used and analyzed during the current study available from the corresponding author on reasonable request.

\section{Authors' contributions}

SW carried out the experiment and collected the data; $\mathrm{YH}$ participated in hormonal analysis, as well as wrote the manuscript; AL participated 2-DE data collection as well as contributed in English editing and revision of the manuscript; $\mathrm{Cl}$ participated in hormones analysis; IJ supervised the overall experiment and revised the manuscript. All authors read and approved the final manuscript.

\section{Ethics approval and consent to participate}

The rice seeds, Dongjin, is very a common and broadly cultivated variety in South Korea. The seeds were procured from the National Institute of Crop Science, Rural Development Administration, South Korea. Our project does not used transgenic technology therefore it does not require ethical approval.

\section{Consent for publication}

Not applicable.

\section{Competing interests}

The authors declare that they have no competing interests.

\section{Publisher's Note}

Springer Nature remains neutral with regard to jurisdictional claims in published maps and institutional affiliations.

\section{Author details}

${ }^{1}$ Natural Resources Research Institute, R\&D Headquarters, Korea Ginseng Corporation, Daejeon 34128, South Korea. ²Division of Plant Biosciences, Kyungpook National University, Daegu 41566, South Korea. ${ }^{3}$ UoN Chair of Oman's Medicinal Plants \& Marine Natural Products, University of Nizwa, 616 
Nizwa, Oman. ${ }^{4}$ Department of Agronomy, Gyeongsang National University, Jinju 52828, South Korea. ${ }^{5}$ Crop Physiology Laboratory, Division of Plant Biosciences, Kyungpook National University, Daegu 41566, South Korea.

Received: 25 July 2017 Accepted: 18 December 2017

Published online: 04 January 2018

\section{References}

1. Mitani N, Chiba Y, Yamaji N, Ma JF. Identification and characterization of maize and barley Lsiz-like silicon efflux transporters reveals a distinct silicon uptake system from that in rice. Plant Cell. 2009:21:2133-42.

2. Yamaji N, Chiba Y, Mitani-Ueno N, Ma JF. Functional characterization of a silicon transporter gene implicated in silicon distribution in barley. Plant Physiol. 2012;160:1491-7.

3. Feng J, Shi Q, Wang X. Effects of exogenous silicon on photosynthetic capacity and antioxidant enzyme activities in chloroplast of cucumber seedlings under excess manganese. Agri. Sci China. 2009;8:40-50.

4. Kim YH, Khan AL, Kim DH, Lee SY, Kim KM, Waqas M, Jung HY, Shin JH, Kim $J G$, Lee IJ. Silicon mitigates heavy metal stress by regulating P-type heavy metal ATPases, Oryza sativa low silicon genes, and endogenous phytohormones. BMC Plant Biol. 2014;14:13.

5. Kim YH, Khan AL, Waqas M, Shim JK, Kim DH, Lee KY, Lee IJ. Silicon application to rice root zone influenced the phytohormonal and antioxidant responsesunder salinity stress. J Plant Growth Regul. 2014c;33:137-49.

6. Kim YH, Khan AL, Waqas M, Shahzad R, Lee IJ. Silicon-mediated mitigation of wounding stress acts by up-regulating the rice antioxidant system. Cereal Res Commun. 2016b;44:111-21.

7. Ma JF, Tamai K, Yamaji N, Mitani N, Konishi S, Katsuhara M, Ishiguro M, Kurata Y, Yano MA. silicon transporter in rice. Nature. 2006;440:688-91.

8. Hamayun M, Sohn EY, Khan SA, Shinwari ZK, Khan AL, Lee IJ. Silicon alleviates the adverse effects of salinity and drought stress on growth and endogenous plant growth hormones of soybean (Glycine Max L.). Pak J Bot 2010;42:1713-1722

9. Al-aghabary K, Zhu Z, Qinhua S. Influence of silicon supply on chlorophyll content, chlorophyll fluorescence and antioxidative enzyme activities in tomato plants under salt stress. J Plant Nutr. 2005;27:2101-15.

10. Epstein E. Silicon: Ann Rev. Plant Physiol Mol Biol. 1999;50:641-64.

11. Kim YH, Khan AL, Lee IJ. Silicon: a duo synergy for regulating crop growth and hormonal signaling under abiotic stress conditions. Crit Rev Biotechnol. 2016c;36:1099-109.

12. Raven J. The transport and function of silicon in plants. Biol Rev. 1983;58: 179-207.

13. Yamaji N, Mitatni N, Ma JFA. Transporter regulating silicon distribution in rice shoots. Plant Cell. 2008:20:1381-9.

14. Barber SA. Soil nutrient bioavailability: a mechanistic approach. 2nd ed. New York: Wiley; 1995.

15. Gilliham M, Dayod M, Hocking BJ, Xu B, Conn SJ, Kaiser BN, Leigh RA, Tyerman SD. Calcium delivery and storage in plant leaves: exploring the link with water flow. J Exp Bot. 2011;62:2233-50.

16. Kudla J, Batistič O, Hashimoto K. Calcium signals: the lead currency of plant information processing. Plant Cell. 2010;22:541-63.

17. Zhao D, Reddy KR, Kakani VG, Reddy VR. Nitrogen deficiency effects on plant growth, leaf photosynthesis, and hyperspectral reflectance properties of sorghum. Eur J Agron. 2005;22:391-403.

18. Murphy CJ, Baggs EM, Morley N, Wall DP, Paterson E. Nitrogen availability alters rhizosphere processes mediating soil organic matter mineralisation. Plant Soil. 2017; https://doi.org/10.1007/s11104-017-3275-0.

19. Salman D, Morteza S, Dariush Z, Nasiri A, Reza Y, Ehsan GD, Reza NNA. Application of nitrogen and silicon rates on morphological and chemical lodging related characteristics in rice (Oryza sativa L.) at North of Iran. J Agri Sci. 2012;4(6):12-8. https://doi.org/10.5539/jas.v4n6p12.

20. Wu X, Yu Y, Baerson SR, Song Y, Liang G, Ding C, Niu J, Pan Z, Zeng R. Interactions between nitrogen and silicon in rice and their effects on resistance toward the brown planthopper Nilaparvata lugens. Front Plant Sci. 2017;8:28. https://doi.org/10.3389/fpls.2017.00028.

21. Neu S, Schaller J, Dudel EG. Silicon availability modifies nutrient use efficiency and content, C: N: P stoichiometry, and productivity of winter wheat (Triticum aestivum L.). Sci Rep. 2017;7:40829. https://doi.org/10.1038/ srep40829.

22. Walter A, Schurr U. Dynamics of leaf and root growth: endogenous contro versus environmental impact. Ann Bot. 2005;95:891-900.
23. Hwang SJ, Hamayun M, Kim HY, Na Cl, Kim KU, Shin DH, Kim SY, Lee IJ. Effect of nitrogen and silicon nutrition on bioactive gibberellin and growth of rice under field conditions. J crop Sci. Biotech. 2007;10:281-6.

24. Sivanesan, I., Jeong, B.R. Silicon promotes adventitious shoot regeneration and enhances salinity tolerance of Ajuga multiflora Bunge by altering activity of antioxidant enzyme. Sci World J. 2014. https://doi.org/10.1155/ 2014/521703.

25. Kim YH, Khan AL, Waqas $M$, Lee IJ. Silicon regulates antioxidant activities of crop plants under abiotic-induced oxidative stress: a review. Front Plant Sci. 2017:8:510. https://doi.org/10.3389/fpls.2017.00510.

26. Cooke J, Leishman MRI. Plant ecology more siliceous than we realise. Trends Plant Sci. 2011;16:61-8.

27. Jang SW, Hamayun M, Sohn EY, Shin DH, Kim KU, Lee IJ. Studies on the effect of silicon nutrition on plant growth, mineral contents and endogenous gibberellins of three rice cultivars. J crop Sci. Biotech. 2007;10: 47-51.

28. Savant NK, Snyder GH, Datnoff LE. Silicon management and sustainable rice production. Adv Agron. 1996;58:151-99.

29. Tripathi DK, Singh VP, Chauhan DK, Prasad SM. Silicon in plants: advances and future prospects. New York: CRC Press, Taylor \& Francis Group; 2017.

30. Tripathi DK, Singh S, Singh VP, Prasad SM, Dubey NK, Chauhan DK. Silicon nanoparticles more effectively alleviated UV-B stress than silicon in wheat (Triticum aestivum) seedlings. Plant Physiol Biochem. 2017b;110:70-81.

31. Ma JF. Role of silicon in enhancing the resistance of plants to biotic and abiotic stresses. Soil Sci Plant Nutr. 2004:50:11-8.

32. Yoshida S, Ohnishi Y, Kitagishi K. Role of silicon in rice nutrition. Soil Plant Food. 1959:5:127-33.

33. Lee IJ, Foster KR, Morgan PW. Photoperiod control of gibberellin levels and flowering in sorghum. Plant Physiol. 1998;116:1003-11.

34. Kim YH, Ahn IO, Khan AL, Kamran M, Waqas M, Lee JS, Kim DH, Jang SW, Lee IJ. Regulation of endogenous gibberellins and abscisic acid levels during different seed collection periods in Panax ginseng. Hort Environ Biotechnol. 2014a;55:166-74

35. McCloud ES, Baldwin IT. Herbivory and caterpillar regurgitants amplify the wound-induced increases in jasmonic acid but not nicotine in Nicotiana sylvestris. Planta. 1997;203:430-5.

36. Enyedi AJ, Yalpani N, Silverman P, Raskin I. Localization, conjugation, and function of salicylic acid in tobacco during the hypersensitive reaction to tobacco mosaic virus. Proc Natl Acad Sci U S A. 1992;89:2480-4.

37. Seskar M, Shulaev V, Raskin I. Endogenous methyl salicylate in pathogeninoculated tobacco plants. Plant Physiol. 1998;1 16:387-92.

38. Choi KY, Lee YB. Effect of salinity of nutrient solution on growth, translocation and accumulation of ${ }^{45} \mathrm{Ca}$ in butterhead lettuce. In International Symposium on Growing Media and Hydroponics. 1999;548: $575-80$.

39. Bradford MMA. Rapid and sensitive method for the quantitation of microgram quantities of protein utilizing the principle of protein-dye binding. Anal Biochem. 1976;72(1-2):248-54.

40. Blum H, Beier H, Gross HJ. Improved silver staining of plant proteins, RNA and DNA in polyacrylamide gels. Electrophoresis. 1987;8:93-9.

41. Carpentier SC, Witters E, Laukens K, Deckers P, Swennen R, Panis B. Preparation of protein extracts from recalcitrant plant tissues: an evaluation of different methods for two-dimensional gel electrophoresis analysis. Proteomics. 2005;5:2497-507.

42. Feinberg AP, Vogelstein BA. Technique for radiolabeling DNA restriction endonuclease fragments to high specific activity. Anal Biochem. 1983; 132:6-13

43. Luyckx M, Hausman JF, Lutts S, Guerriero G. Silicon and plants: current knowledge and technological perspectives. Front Plant Sci. 2017;8: doi.org/ https://doi.org/10.3389/fpls.2017.00411.

44. Song A, Xue G, Cui P, Fan F, Liu H, Yin C, Sun W, Liang Y. The role of silicon in enhancing resistance to bacterial blight of hydroponic-and soil-cultured rice. Sci Rep. 2016;6 https://doi.org/10.1038/srep24640.

45. Deshmukh R, Bélanger RR. Molecular evolution of auaporins and silicon influx in plants. Funct Ecol. 2016;30:1277-85.

46. Datnoff LE, Snyder GH, Korndörfer GH. "Silicon in agriculture." in the Elsevier, Amsterdam: Korndörfer and Lepsch. 2001. p. 133-47.

47. Hirel B, Le Gouis J, Ney B, Gallais A. The challenge of improving nitrogen use efficiency in crop plants: towards a more central role for genetic variability and quantitative genetics within integrated approaches. J Exp Bot. 2007;58:2369-87. 
48. Hussain A, Mun BG, Imran QM, Lee SU, Adamu TA, Shahid M, Kim KM, Yun BW. Nitric oxide mediated transcriptome profiling reveals activation of multiple regulatory pathways in Arabidopsis thaliana. Front Plant Sci. 2016;7 https://doi.org/10.3389/fpls.2016.00975.

49. Schulten HR, Schnitzer M. The chemistry of soil organic nitrogen: a review. Biol Fertil Soils. 1997;26:1-15.

50. Epstein E. Mineral nutrition of plants: principles and perspectives. New York: Wiley; 1972

51. Evans HJ, Sorger GJ. Role of mineral elements with emphasis on the univalent cations. Ann rev. Plant Physiol. 1966;17:47-76.

52. Mae T. Physiological nitrogen efficiency in rice: nitrogen utilization, photosynthesis, and yield potential. Plant Soil. 1997;196:201-10.

53. Cho YS, Jeon WT, Park CY, Park KD, Kang UG. Study of nutrient uptake and physiological characteristics of rice by ${ }^{15} \mathrm{~N}$ and purified Si fertilization level in a transplanted pot experiment. Korean. J Crop Sci. 2006;51:408-19.

54. Jawahar S, Vaiyapuri V. Effect of sulphur and silicon fertilization on growth and yield of rice. Int J Curr Res. 2010;9:36-8.

55. Bian R, Li L, Bao D, Zheng J, Zhang X, Zheng J, Liu X, Cheng K, Pan G. Cd immobilization in a contaminated rice paddy by inorganic stabilizers of calcium hydroxide and silicon slag and by organic stabilizer of biochar. Environ Sci Pollut Res. 2016;23:10028-36.

56. Ma JF, Takahashi E. Effect of silicic acid on phosphorus uptake by rice plant. Soil Sci Plant Nut. 1989;35:227-34

57. Kaya C, Tuna L, Higgs D. Effect of silicon on plant growth and mineral nutrition of maize grown under water-stress conditions. J Plant Nut. 2006; 29:1469-80

58. Xi J, Qiu Y, Du L, Poovaiah BW. Plant-specific trihelix transcription factor AtGT2L interacts with calcium/calmodulin and responds to cold and salt stresses. Plant Sci. 2012;185:274-80.

59. Colebrook EH, Thomas SG, Phillips AL, Hedden P. The role of gibberellin signalling in plant responses to abiotic stress. J Exp Biol. 2014;217:67-75

60. Reber M, Kaneta T, Kawaide H, Kamiya Y. Regulaton of gibberellin biosynthesis genes during flower and fruit development of tomato. The. Plant J. 1999;17:241-50.

61. Kim YH, Choi Kl, Khan AL, Waqas M, Lee IJ. Exogenous application of abscisic regulates endogenous gibberellins homeostasis and enhances resistance of oriental melon (Cucumis melo Var. L.) against low temperature. Sci Hort. 2016;207:41-7.

62. Kim YH, Hwang SJ, Waqas M, Khan AL, Lee JH, Lee JD, Nguyen HT, Lee IJ. Comparative analysis of endogenous hormones level in two soybean (Glycine max L.) lines differing in waterlogging tolerance. Front Plant Sci. 2015:6:714. https://doi.org/10.3389/fpls.2015.00714.

63. Nishiuchi S, Yamauchi T, Takahashi H, Kotula L, Nakazono M. Mechanisms for coping with submergence and waterlogging in rice. Rice. 2012;5(1):2. https://doi.org/10.1186/1939-8433-5-2.

64. Shani E, Weinstain R, Zhang Y, Castillejo C, Kaiserli E, Chory J, Tsien RY, Estelle M. Gibberellins accumulate in the elongating endodermal cells of Arabidopsis root. Proc Nat Acad Sci USA. 2013;110:4834-9.

65. Goetz S, Hellwege A, Stenzel I, Kutter C, Hauptmann V, Forner S, McCaig B, Hause G, Miersch O, Wasternack C, Hause B. Role of cis-12-oxo-phytodienoic acid in tomato embryo development. Plant Physiol. 2012;158:1715-27.

66. He Y, Fukushige $H$, Hildebrand DF, Gan S. Evidence supporting a role of jasmonic acid in Arabidopsis leaf senescence. Plant Physiol. 2002;128: 876-84.

67. Cenzano A, Vigliocco A, Kraus T, Abdala G. Exogenously applied jasmonic acid induces changes in apical meristem morphology of potato stolons. Annals Bot. 2003:91:915-9.

68. Yang F, Zhang Y, Huang Q, Yin G, Pennerman KK, Yu J, Liu Z, Guo A. Analysis of key genes of jasmonic acid mediated signal pathway for defense against insect damages by comparative transcriptome sequencing. Sci Rep. 2015;5:16500.

69. Ahmad P, Rasool S, Gul A, Sheikh SA, Akram NA, Ashraf M, Kazi AM, Gucel S. Jasmonates: multifunctional roles in stress tolerance. Front Plant Sci. 2016;7 https://doi.org/10.3389/fpls.2016.00813.

70. Pieterse CM, Van d. Does D, Zamioudis C, Leon-Reyes a, van Wees SC. Hormonal modulation of plant immunity. Ann Rev Cell Dev Biol. 2012;28: 489-521.

71. Currie HA, Perry CC. Silica in plants: biological, biochemical and chemical studies. Ann Bot. 2007;100:1383-9.
72. Kim YH, Khan AL, Waqas M, Jeong HJ, Kim DH, Shin JS, Kim JG, Yeon MH, Lee IJ. Regulation of jasmonic acid biosynthesis by silicon application during physical injury to Oryza sativa L. J Plant Res. 2014;127:525-32.

73. Gong H, Zhu X, Chen K, Wang S, Zhang C. Silicon alleviates oxidative damage of wheat plants in pots under drought. Plant Sci. 2005;169:313-21.

74. Kim YH, Khan AL, Hamayun M, Kang SM, Beom YJ, Lee IJ. Influence of short-term silicon application on endogenous physiohormonal levels of Oryza sativa L. under wounding stress. Biol Trace Elem Res. 2011;144: $1175-85$.

75. Jiang CJ, Shoji K, Matsuki R, Baba A, Inagaki N, Ban H, Iwasaki T, Imamoto N, Yoneda Y, Deng XW, Yamamoto N. Molecular cloning of a novel importin a homologue from rice, by which constitutive photomorphogenic 1 (COP1) nuclear localization signal (NLS)-protein is preferentially nuclear imported. J Biol Chem. 2001;276:9322-9.

76. Yamamoto N, Deng XW. Protein nucleocytoplasmic transport and its light regulation in plants. Genes Cells. 1999;4:489-500.

77. Hirota T, Tsuboi H, lizuka-Koga M, Takahashi H, Asashima H, Yokosawa M, Kondo Y, Ohta M, Wakasa Y, Matsumoto I, Takaiwa F, Sumida T. Suppression of glucose-6-phosphate-isomerase induced arthritis by oral administration of transgenic rice seeds expressing altered peptide ligands of glucose-6phosphate-isomerase. Mod Rheumatol. 2017;27:457-6.

78. Lee JH, Chang KZ, Patel V, Jeffery CJ. Crystal structure of rabbit phosphoglucose isomerase complexed with its substrate D-fructose 6phosphate. Biochemist. 2001;40:7799-805.

79. Das P, Seal P, Biswas AK. Regulation of growth, antioxidants and sugar metabolism in rice (Oryza sativa L.) seedlings by $\mathrm{NaCl}$ and its reversal by silicon. Am. J. Plant Sci. 2016;7:623.

\section{Submit your next manuscript to BioMed Central and we will help you at every step:}

- We accept pre-submission inquiries

- Our selector tool helps you to find the most relevant journal

- We provide round the clock customer support

- Convenient online submission

- Thorough peer review

- Inclusion in PubMed and all major indexing services

- Maximum visibility for your research

Submit your manuscript at www.biomedcentral.com/submit 